\title{
Effects of New Growth Hormone-Releasing Peptide (KP 102) on the Release of Growth Hormone in vitro and in vivo in Cattle
}

\author{
Tsutomu HASHIZUME, Masazumi YANAGIMOTO, \\ Syu KAINUMA, Risa NAGANO, \\ Keiko MORIWAKI, Kenji OHTSUKI, \\ Koichi SASAKI, Hiroshi MASUDA \\ and Toh-ichi HIRATA
}

Faculty of Agriculture, Iwate University, Morioka-shi 020

(Received December 13, 1996)

\begin{abstract}
The effects of KP 102 (also named GHRP-2), a new growth hormone-releasing peptide, on the release of bovine grow th hormone $(\mathrm{GH})$ were examined in vitro and in vivo. KP 102 and GH-releasing hormone (GHRH : hGHRH(1-29)- $\mathrm{NH}_{2}$ ) significantly $(\mathrm{P}<0.05)$ stimulated GH release from cultured bovine anterior pituitary cells at doses as low as $10^{-11} \mathrm{M}$ and $10^{-13} \mathrm{M}$, respectively. When KP $102\left(10^{-8} \mathrm{M}\right)$ and GHRH $\left(10^{-8} \mathrm{M}\right.$ or $\left.10^{-10} \mathrm{M}\right)$ were added together, the additive effects of both peptides on the release of GH were observed $(P<0.05)$. Somatostatin (SS, $\left.10^{-7} \mathrm{M}\right)$ significantly $(\mathrm{P}<0.05)$ blunted $\mathrm{GH}$ release induced by KP $102\left(10^{-8} \mathrm{M}\right)$ and GHRH $\left(10^{-8} \mathrm{M}\right)$. Under the presence of SS, the additive effects of KP 102 and GHRH on the release of GH were also observed $(\mathrm{P}<0.05)$. Intravenous injection of $20 \mu \mathrm{g} / \mathrm{kg}$ BW KP 102 significantly $(\mathrm{P}<0.05)$ stimulated GH release in calves. Plasma GH concentrations 10 and 20 min after the iv injection of $\mathrm{KP} 102(20 \mu \mathrm{g} / \mathrm{kg} \mathrm{BW})$ plus GHRH $(0.25 \mu \mathrm{g} / \mathrm{kg} \mathrm{BW})$ were significantly $(\mathrm{P}<0.05)$ greater than those of either KP 102 alone or GHRH alone. The value of the area under the GH response curve for 60 min in GHRH alone and KP 102 plus GHRH was significantly $(\mathrm{P}<0.05)$ greater than that of KP 102 alone; however, there were no significant differences between the KP 102 plus GHRH and the GHRH alone groups. These results show that KP 102 stimulates GH release in cattle, and KP 102 interacts with GHRH and SS to release bovine GH.
\end{abstract}

Anim. Sci. Technol. (Jpn.) 68 (5) : 450-458, 1997

Key words : KP 102, GHRP-2, GHRH, GH, Cattle

Growth hormone-releasing peptides (GHRPs) are a family of synthetic peptides, six to seven amino acids in size, which selectively stimulate GH release ${ }^{5,17,18)}$. The first GHRP identified, His-D-Trp-Ala-Trp-D-Phe-Lys-NH ${ }_{2}$ (GHRP6 , was derived from the pentapeptide metenkephalin through theoretic low-energy conformational calculations, computer modeling, structural modification, and biologic studies ${ }^{19}$. GHRP-6 stimulates $\mathrm{GH}$ release in many species ${ }^{2.17)}$, and the peptide acts at both the pituitary and hypothalamic levels to release $\mathrm{GH}^{11,17)}$. Recently, newly developed analogues of GHRP-6 have been synthesized and reported to be potent $\mathrm{GH}$ secretagogues ${ }^{5,17.18,20,22,28,29)}$. At present KP 102 (also named GHRP-2), D-Ala $-\mathrm{D}-\beta \mathrm{Nal}-\mathrm{Ala}-\mathrm{Trp}-\mathrm{D}-\mathrm{Phe}-\mathrm{Lys}-\mathrm{NH}_{2}$, seems to be the most potent one. In cultured ovine pituitary cells, GHRP-6 had $10 \%$ of the potency of $\mathrm{GH}$-releasing hormone $(\mathrm{GHRH})^{29)}$; however, KP 102 is equipotent with GHRH as a GH secretagogue for ovine pituitary cells ${ }^{28)}$. The 
detailed mechanism of action of KP 102 is not clear, and the effects of KP 102 on the release of $\mathrm{GH}$ have not been fully elucidated yet in cattle either in vitro and in vivo. GHRP-6 has been shown to increase the rate of milk production in cows ${ }^{8)}$, and KP 102 has been suggested to be used for enhancing the growth performance in cattle $^{21)}$. Infusion of GHRH increase the mean and pulsatile release of $\mathrm{GH}$ and increase milk yield in cows $\mathrm{s}^{9,10)}$. Moreover, KP 102 and GHRH administered together synergistically stimulates $G H$ release in rats ${ }^{22}$ and humans ${ }^{20)}$. It is therefore important to clarify the GH-releasing response to KP 102 and GHRH in cattle for the effective usage of the peptides in milk and meat production.

The present study was designed to examine the effect of KP 102 on the release of GH with the interactive effects of GHRH and somatostatin (SS) using bovine cultured anterior pituitary cells in vitro. In addition, the GH responses to the combination of KP 102 plus GHRH were examined complementarily in vivo in cattle.

\section{Materials and Methods}

\section{Hormones and chemicals}

Peptides and chemicals were obtained from the following sources: KP 102 (a generous gift from Kaken Pharmaceutical Co. Ltd., Urayasu, Japan); GHRH (hGHRH(1-29)- $\mathrm{NH}_{2}$, a generous gift from Dr. S. Ohashi, National Institute of Bioscience and Human Technology, Tsukuba, Japan) ; SS (Somatostatin-14, Peptide Institute Inc., Osaka, Japan) ; Dulbecco's modified Eagle Medium (DMEM), horse serum, newborn calf serum, pancreatin $4 \mathrm{X}, \mathrm{N}$-2-hydroxyethyl piperazine- $\mathrm{N}^{\prime}-2$-ethanesulfonic acid (HEPES) and non-essential amino acids (Gibco, Gland Island, NY, USA) ; collagenase (Wako Pure Chemical Industries LTD., Osaka, Japan) and bovine serum albumin (BSA) (Boehringer Mannheim, Germany).

Adenohypophysial cell dissociation and culture
The pituitary glands were obtained from 12 Holstein steers (age : 17-18 months) at a local slaughterhouse and transported to the laboratory in DMEM medium to which was added $15 \mathrm{mM}$ HEPES, $50 \mu \mathrm{g}$ streptomycin $/ \mathrm{m} l$, and 100 $\mathrm{IU}$ penicillin $/ \mathrm{m} l$ at $5^{\circ} \mathrm{C}$ within $2 \mathrm{~h}$. The cell cultures of the anterior pituitary (AP) cells were prepared as previously described by Vale et $a l_{.}{ }^{26)}$ and modified in our laboratory ${ }^{13)}$. In brief, the AP cells were resuspended in DMEM medium containing 10\% horse serum, $2.5 \%$ newborn calf serum, $1 \%$ non-essential amino acids $(100 \mathrm{x}), 100 \mathrm{IU} / \mathrm{m} l$ penicillin, and $50 \mu \mathrm{g} / \mathrm{ml}$ streptomycin. The cells $\left(7 \times 10^{4}\right.$ cells $\left./ \mathrm{m} l\right)$ were then plated in Costar $24-$ well dishes and maintained at $37^{\circ} \mathrm{C}$ in a humidified atmosphere of $5 \% \mathrm{CO}_{2}$. The media were changed 2 days after plating. After 3.5 days culture, the cells were washed twice with DMEM only supplemented with $0.1 \% \mathrm{BSA}$, and the media were replaced with the fresh media containing the peptides to be tested; the cells were then incubated for $2 \mathrm{~h}$ except for time-courses of experiments for $\mathrm{GH}$ release. At the end of incubation, the media were removed from the cells and stored at $-20^{\circ} \mathrm{C}$ until assayed for $\mathrm{GH}$.

$G H$ responses to a single iv injection of KP 102, GHRH, and KP102 plus GHRH

The experiments were performed between May and June, using five female Holstein calves (age, 6-9 months; mean body weight, $134 \mathrm{~kg}$ ). The calves were housed in pens, and natural light was allowed to enter through windows. The calves were fed grass silage and concentrate at $0930 \mathrm{~h}$ and $1600 \mathrm{~h}$ daily. Water was available continuously. On the day of the experiment, they were not fed either before or during the experiment; they were fed only after the experiment. The jugular venous blood of the experimental animals was sampled from the indwelling catheter previously inserted into one of the external jugular veins. The animals were given a single iv injection of KP102 $(20 \mu \mathrm{g} / \mathrm{kg} \mathrm{BW})$, GHRH $(0.25$ $\mu \mathrm{g} / \mathrm{kg} \mathrm{BW}), \mathrm{KP} 102(20 \mu \mathrm{g} / \mathrm{kg} \mathrm{BW})$ plus GHRH 
$(0.25 \mu \mathrm{g} / \mathrm{kg} \mathrm{BW})$, and $5 \mathrm{~m} l$ saline (as a control). The agents were injected via the indwelling catheter. The animals were repeatedly used for each treatment, and the experiments were carried out at one-week intervals. The blood samples (one $\mathrm{m} l$ each) were drawn at $-30,-20$, $-10,0$ (just before injection), 10,20,30, 40,50,60, $70,80,90,105,120,135,150,165$ and 180 min after injection. The blood samples were collected into centrifuge tubes containing heparin and were immediately chilled with ice. Individual plasma samples were obtained after centrifugation and stored at $-20^{\circ} \mathrm{C}$ until assayed.

\section{Radioimmunoassay (RIA)}

Bovine GH concentrations in media and plasma were measured by a validated RIA method as previously described ${ }^{16)}$. The GH standard preparation and hormone for iodination was bGH-B-1. In these assays, the displacement curve for increasing volumes of the culture medium pool and bovine serum pool was parallel to the standard curve. The least detectable value was $0.1 \mathrm{ng} / \mathrm{tube}$. The intraand inter-assay coefficients of variation were $7.3 \%$ and $13.5 \%$, respectively.

\section{Statistical analysis}

In in vitro experiments, there were 4 to 6 wells per treatment and the experiments were repeated three to five times with different pituitary glands. All data in the in vitro and in vivo experiments were presented as mean \pm $\mathrm{SE}$. Statistical significance of the differences in $\mathrm{GH}$ concentrations was analysed by one way analyses of variance, and differences between specific groups were determined by subsequent use of Duncan's multiple range test ${ }^{27}$. Linear regression analyses by SAS were conducted to evaluate changes in media GH release over the concentrations of KP102 and GHRH.

\section{Results}

GH-releasing effects of KP102 and GHRH from cultured bovine adenohypophysial cells

As shown in Figs. 1 and 2, KP 102 and GHRH

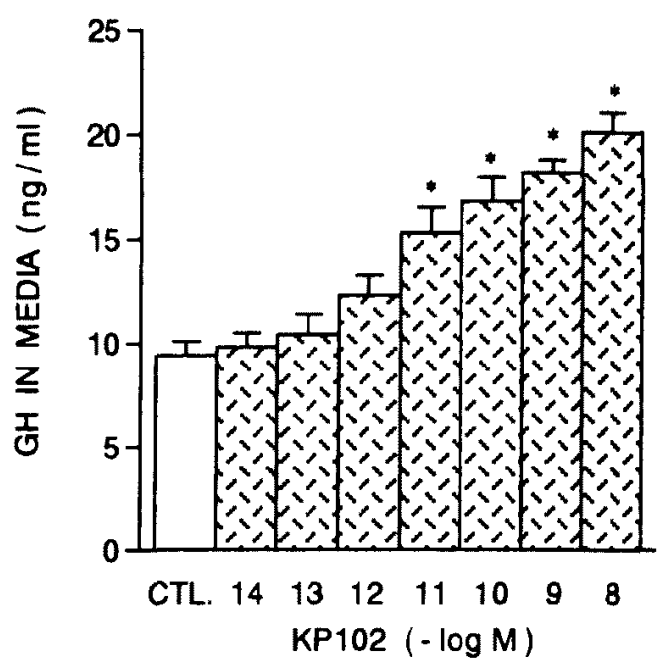

Fig. 1. Effects of KP102 $\left(10^{-14}\right.$ to $\left.10^{-8} \mathrm{M}\right)$ on the release of $\mathrm{GH}$ from cultured bovine anterior pituitary cells over a $2-\mathrm{h}$ incubation period. There were four wells per treatment and the experiment was repeated three times with three cifferent pituitary glands. Each value represents the mean of twelve wells \pm SE. Significant differences from controls are indicated by asterisks $\left({ }^{*} \mathrm{P}<0.05\right)$.

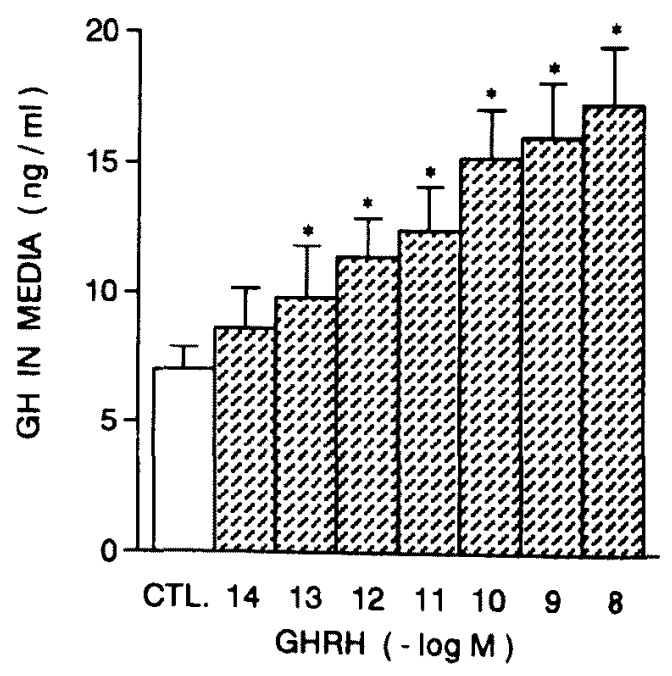

Fig. 2. Effects of GHRH $\left(10^{-14}\right.$ to $\left.10^{-8} \mathrm{M}\right)$ on the release of $\mathrm{GH}$ from cultured bovine anterior pituitary cells over a $2-\mathrm{h}$ incubation period. Other explanations are shown in Fig. I. 
significantly increased bovine GH concentrations in cultured media after $2 \mathrm{~h}$ incubation at doses as low as $10^{-11} \mathrm{M}$ and $10^{-13} \mathrm{M}$, respectiveIy $(\mathrm{P}<0.05)$. Based on linear regression analysis, KP $102\left(10^{-8}\right.$ to $\left.10^{-13} \mathrm{M}\right)$ and GHRH $\left(10^{-8}\right.$ to $10^{-14} \mathrm{M}$ ) stimulated the release of $\mathrm{GH}$ in a dosedependent manner $(\mathrm{P}<0.05)$. Effect of incubation time on KP $102\left(10^{-8} \mathrm{M}\right)-$ and GHRH $\left(10^{-8}\right.$ $\mathrm{M})$-stimulated bovine $\mathrm{GH}$ release was shown in Fig. 3. Both KP 102 and GHRH significantly (P $<0.05$ ) increased $\mathrm{GH}$ release for 15,60 , and 120 min incubation. $\mathrm{GH}$ concentrations after treatment with GHRH were significantly $(\mathrm{P}<$ $0.05)$ greater than those of KP 102 both for 60 and $120 \mathrm{~min}$ incubation. The maximum responses of GH release to KP102 and GHRH were observed after $60 \mathrm{~min}$ and $120 \mathrm{~min}$ incubation, respectively.

Combined effects of KP 102 and GHRH on GH release from cultured bovine adenohypophysial cells

As shown in Fig, 4, KP $102\left(10^{-8} \mathrm{M}\right)$ and GHRH $\left(10^{-8}\right.$ or $\left.10^{-10} \mathrm{M}\right)$ and combined treatment with KP 102 plus GHRH induced significant increases in the $\mathrm{GH}$ concentration in

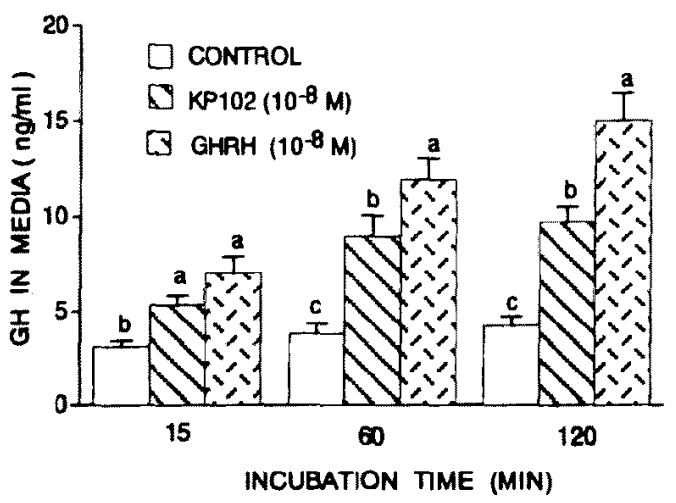

Fig. 3. Effects of incubation time on KP102- and GHRH-stimulated bovine GH release. There were eight wells per treatment and the experiment was repeated three times with three different pituitary glands. Each value represents the mean of twenty four wells $\pm S E$. The different letters on the bar in each incubation time denote significant differences $(\mathrm{P}<0.05)$. media compared with the controls $(\mathrm{P}<0.05)$. When KP 102 and $10^{-8} \mathrm{M}$ GHRH were added together, the release of $\mathrm{GH}$ induced by both peptides was significantly greater than those by either KP 102 or GHRH alone $(\mathrm{P}<0.05)$. The percent increase in $\mathrm{GH}$ released with KP 102 and $10^{-8} \mathrm{M}$ GHRH together was $102 \%$ and $36 \%$ greater than those by either KP 102 or GHRH alone, respectively. When KP 102 and $10^{-10} \mathrm{M}$ GHRH were added together, the release of $\mathrm{GH}$ induced by both peptides was significantly greater than those by either KP 102 or GHRH alone $(\mathrm{P}<0.05)$. The percent increase in $\mathrm{GH}$ released with KP 102 and $10^{-10} \mathrm{M} \mathrm{GHRH}$ together was $102 \%$ and $51 \%$ greater than those by either KP 102 or GHRH alone, respectively.

Effects of SS on KP102- and GHRH-induced GH release from cultured bovine adenohypophysial cells

Fig. 5 shows the combined effect of KP 102 $\left(10^{-8} \mathrm{M}\right)$, GHRH $\left(10^{-8} \mathrm{M}\right)$, and SS $\left(10^{-7} \mathrm{M}\right)$ on $\mathrm{GH}$

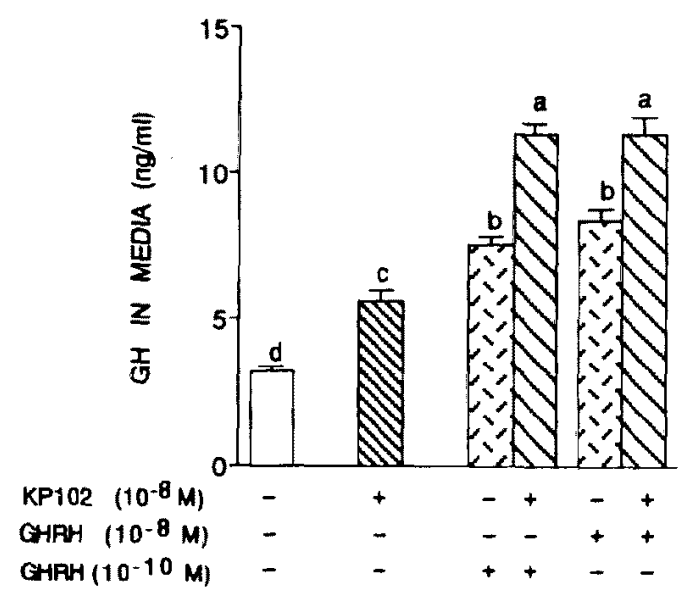

Fig. 4. The combined effects of KP $102\left(10^{-8} \mathrm{M}\right)$ and GHRH $\left(10^{-8} \mathrm{M}\right.$ or $\left.10^{-30} \mathrm{M}\right)$ on the release of GH from cultured bovine anterior pituitary cells over a 2 -h incubation period. There were four wells per treatment and the experiment was repeated three times with three different pituitary glands, Each value represents the mean of twelve wells $\pm \mathrm{SE}-$ : Absence of a substance(s) in a media. + : Presence of a substance (s) in a media. The different letters on the bar denote significant differences $(P<0.05)$. 


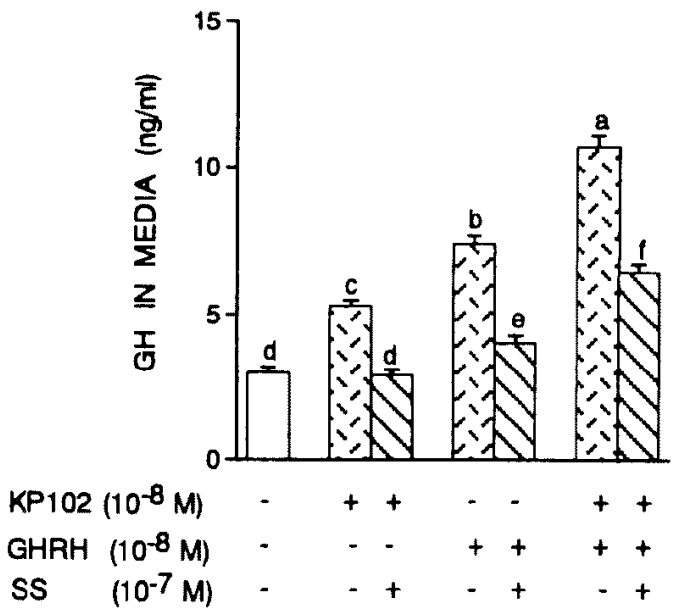

Fig. 5. The combined effects of KP $102\left(10^{-8}\right.$ $\mathrm{M})$, GHRH $\left(10^{-8} \mathrm{M}\right)$, and somatostatin (SS, $10^{-7} \mathrm{M}$ ) on the release of $\mathrm{GH}$ from cultured bovine anterior pituitary cells over a $2-\mathrm{h}$ incubation period. There were six wells per treatment and the experiment was repeated five times with five different pituitary glands. Each value represents the mean of thirty wells $\pm \mathrm{SE}$. Other explanations are shown in Fig. 4. release. The SS significantly blunted KP 102or GHRH-induced increase in bovine $\mathrm{GH}$ when compared with the KP 102 alone or with the GHRH alone, respectively $(\mathrm{P}<0.05)$. GH concentrations after combined treatments SS with KP 102 plus GHRH were significantly suppressed when compared with the KP 102 plus GHRH $(\mathrm{P}<0.05)$, but they were significantly greater than those of the SS with the KP 102 alone or with the GHRH alone $(\mathrm{P}<$ 0.05). Under the presence of $\mathrm{SS}$, the percent increase in GH released with KP 102 plus GHRH was $121 \%$ and $60 \%$ greater than those by either KP 102 or GHRH alone, respectively.

\section{$G H$ responses to a single iv injection of $K P 102$, GHRH, and KP102 plus GHRH}

The responses to plasma $G H$ in calves to a single iv injection of KP 102 , GHRH or KP 102 plus GHRH, and saline are shown in Fig. 6. Saline injections did not alter the basal GH concentrations. On the other hand, plasma $\mathrm{GH}$ increased immediately following the injection of $20 \mu \mathrm{g} / \mathrm{kg} \mathrm{BW}$ of KP $102,0.25 \mu \mathrm{g} / \mathrm{kg} \mathrm{BW}$

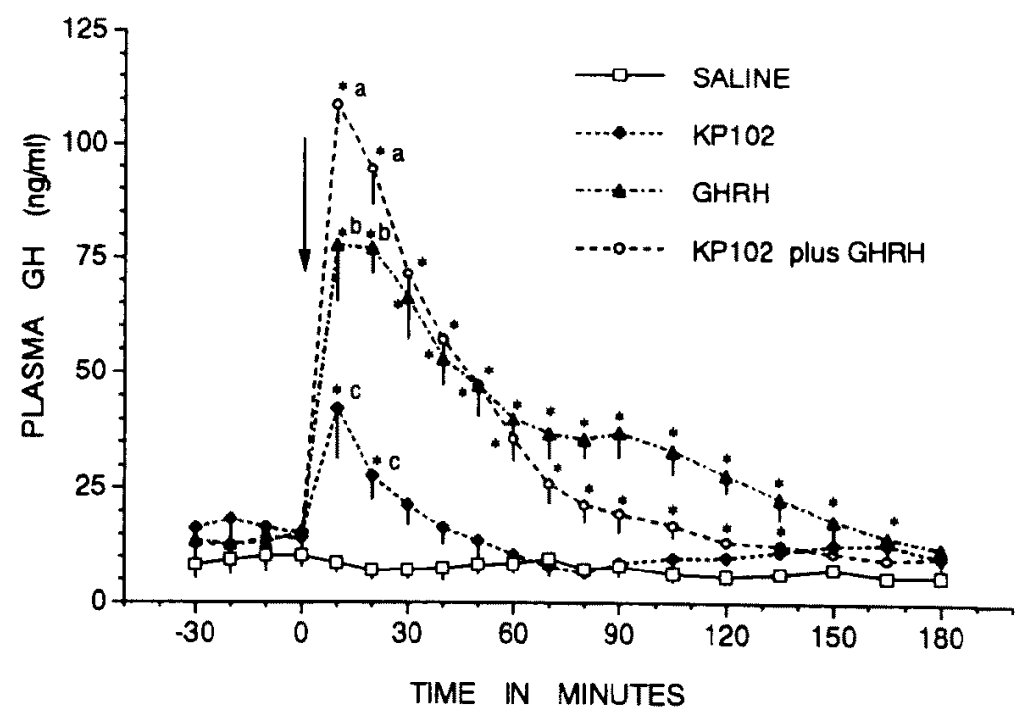

Fig. 6. Plasma GH responses to the iv injections of KP $102(20 \mu \mathrm{g} / \mathrm{kg} \mathrm{BW}$ ), GHRH $(0.25 \mu \mathrm{g} / \mathrm{kg} \mathrm{BW}), \mathrm{KP} 102(20 \mu \mathrm{g} / \mathrm{kg} \mathrm{BW})$ plus GHRH $(0.25 \mu \mathrm{g} / \mathrm{kg} \mathrm{BW})$ or saline in calves. An arrow indicates the time of peptide or saline injection. Each value represents the mean $\pm \mathrm{SE}$ of 5 animals. ${ }^{*} \mathrm{P}<0.05$ compared with the corresponding values of controls. The different letters denote significant differences $(P<0.05)$. 
of GHRH, and $20 \mu \mathrm{g} / \mathrm{kg} \mathrm{BW}$ of KP 102 plus 0.25 $\mu \mathrm{g} / \mathrm{kg}$ BW of GHRH $(\mathrm{P}<0.05)$, and reached maximum mean values of $42 \pm 11$ (mean $\pm S E$ ), $78 \pm 12$, and $108 \pm 4 \mathrm{ng} / \mathrm{ml}$, respectively, from 14 $-15 \mathrm{ng} / \mathrm{m} l$ just before the injection. After the peak levels appeared, GH concentrations began to decrease, and the $\mathrm{GH}$ concentrations in $\mathrm{KP}$ 102, GHRH, and KP 102 plus GHRH returned to the same levels as those of the controls at 60 , 180 , and $150 \mathrm{~min}$, respectively, after each injection. GH concentrations $10 \mathrm{~min}$ after the injection of KP 102 plus GHRH were $157 \%$ and $38 \%$ greater than those by either KP 102 or GHRH alone, respectively $(\mathrm{P}<0.05)$, and $\mathrm{GH}$ concentrations 20 min after the injection of KP 102 plus GHRH were $236 \%$ and $22 \%$ greater than those by either KP 102 or GHRH alone, respectively $(\mathrm{P}<0.05)$. The areas under the $\mathrm{GH}$ response curve (AUC) for $60 \mathrm{~min}$ after the injection of KP $102, G H R H$, and $K P 102$ plus $G H R H$ were $1,340 \pm$ $266,3,488 \pm 412$ and $4,037 \pm 163 \mathrm{ng} \cdot \mathrm{min} \cdot \mathrm{m} l^{-1}$, respectively. The values of the AUC in GHRH alone and KP 102 plus GHRH were significantly $(\mathrm{P}<0.05)$ greater than that of KP 102 alone; however, there were no significant differences between the KP 102 plus GHRH and the GHRH alone groups.

\section{Discussion}

The present study demonstrated that KP 102 stimulates GH release in cattle. As far as we know, the present study is the first investigation to evaluate the direct action of KP 102 on GH secretion from cultured adenohypophysial cells in cattle. The potency of GHRH for GH secretion was greater than that of KP 102 in bovine pituitary cells, and the potency of KP 102 seemed to be similar to that of GHRP- 6 when compared with the results tested in our previous study ${ }^{233}$. Wu et $a l^{28)}$, however, reported that KP 102 was equipotent with GHRH as a GH secretagogue for ovine pituitary cells in vitro. One possible explanation for this discrepancy is a species difference. However, this discrepancy might also be caused by the difference in the experimental procedure. We used a static culture system of bovine anterior pituitary cells and the cells were incubated for $2 \mathrm{~h}$ with the peptide. In contrast to our method, they used a perifusion system of cultured ovine anterior pituitary cells, and the peptides were added for only 8 min during the experiment. The higher potency of the GHRH-stimulated $\mathrm{GH}$ releasing effect over KP 102 was also observed in our time-courses of experiments for $\mathrm{GH}$ release.

An additive effect of KP 102 and GHRH on $\mathrm{GH}$ release was observed when both peptides were added together in the in vitro experiment. Our results in cattle are in agreement with the previous reports in $\operatorname{sheep}^{28)}$. Cheng et al. ${ }^{7}$ ) reportcd that GHRP-6 and GHRH produced a synergistic effect on $G H$ release in rat pituitary cell cultures. Bowers et al. ${ }^{4)}$ demonstrated that a synergistic effect of GHRP-6 and GHRH on $\mathrm{GH}$ release in vitro is only small at best or nonexistent in rats. The mechanism of the action of KP 102 is not clear. KP102, however, has been suggested to act on a novel nonGHRH receptor and use signal transduction systems different from those employed by GHRP $-6^{28)}$.

SS blunted GH release induced by not only GHRH but also KP 102 in vitro. Signal transductions for GH release in GHRH and GHRPs are considered to be different ${ }^{28}$. However, SS blunted GH release induced by both peptides. Therefore, the signal transductions for GH release in GHRH and KP 102 are considered to be the same in some part in cattle. The additive effect of GH release was also observed under the presence of SS. Similar results were reported when GHRP- $6^{23)}$, angiotensin $\mathrm{II}^{25)}$ or PACAP ${ }^{24)}$ were added together with GHRH and SS.

Intravenous injection of KP 102 stimulated $\mathrm{GH}$ release in cattle. However, the potency of KP 102 for GH secretion was weaker than that of GHRH. The dose of KP 102 used in the present study was chosen in consideration of previ- 
ous results in cattle ${ }^{21)}$ and goats ${ }^{14)}$. In cattle, the effective dose of iv injection of KP 102 has been reported more than $12.5 \mu \mathrm{g} / \mathrm{kg} \mathrm{BW}^{21}$. In the goat, iv injection of KP 102 failed to stimulate $\mathrm{GH}$ release at the doses of 5 or $10 \mu \mathrm{g} / \mathrm{kg}$ $\mathrm{BW}$, and the GH release was stimulated by the dose of $20 \mu \mathrm{g} / \mathrm{kg}$ BW. In human, $1 \mu \mathrm{g} / \mathrm{kg} \mathrm{BW}$ of $\mathrm{sc}$ or iv injection of KP 102 stimulates $\mathrm{GH}$ release $^{5,20)}$, and in rats, $0.5 \mu \mathrm{g} / \mathrm{kg} \mathrm{BW}$ of iv injection of KP 102 also stimulates GH release ${ }^{22}$. Therefore, the responsiveness to KP 102 for $\mathrm{GH}$ release in ruminant animals may be weaker than that in human ${ }^{520)}$ and rats ${ }^{22)}$. GHRPs act on both the pituitary and hypothalamus to release $\mathrm{GH}^{17.18)}$. Therefore, the mechanism by which KP 102 stimulated GH release is complicated, although the KP 102 stimulated GH release by acting directly on bovine anterior pituitary cells in our in vitro experiment.

GHRP-6 ${ }^{3.4)}$ or GHRP- ${ }^{53}$ administered together with GHRH synergistically stimulate $\mathrm{GH}$ release in rats ${ }^{4}$ and humans ${ }^{3.5)}$. KP102 and GHRH administered together also synergistically stimulate $\mathrm{GH}$ release in rats $^{22)}$ and humans ${ }^{20)}$. In the present study, $\mathrm{GH}$ concentrations 10 and $20 \mathrm{~min}$ after the injection of KP 102 plus GHRH were significantly greater than those of either KP 102 alone or GHRH alone; however, in the AUC, there were no significant differences between the KP 102 plus GHRH and the GHRH alone groups. Synergistic effects for $\mathrm{GH}$ release by KP 102 and GHRH were also not clear in the goat in our previous study ${ }^{14}$. Therefore, in ruminant animals, typical synergistic effects as shown in rats ${ }^{22}$ and humans ${ }^{20)}$ may not appear. This difference might be due to the difference in GH secretory patterns in the species. GH secretory patterns in ruminant animals ${ }^{12)}$ are different from those in rats ${ }^{12)}$ and human ${ }^{6)}$. The effect of GHRPs on $\mathrm{GH}$ secretion is apparently attenuated by the endogenous GHRH ${ }^{1.15)}$. Therefore, these endocrine backgrounds might affect the sensitivity for KP 102 in GH release, and consequently might affect the synergistic effects.
In conclusion, our results demonstrated that KP 102 stimulated GH release in cattle, and suggested that KP 102 interacted with GHRH and SS to release bovine $\mathrm{GH}$.

\section{Acknowledgments}

The authors wish to thank Dr. T. Johke, National Institute of Animal Industry, Japan, for providing $\mathrm{GH}$ kits, Dr. K. Wakabayashi, the Institute of Endocrinology, Gunma University, Japan, for providing goat anti-monkey IgG serum to bGH and monkey serum, and Dr. S. Ohashi, National Institute of Bioscience and Human Technology, Japan, for providing hGHRH(1-29)- $\mathrm{NH}_{2}$. The authors also thank the USDA Animal Hormone Program, USA for USDA-bGH-B-1 and Kaken Pharmaceutical Co. Ltd., Japan for providing KP 102. Finally, we would like to thank Dr. Paul Langman, Iwate Medical University, for assistance with English usage.

\section{References}

1) Bercu BB, Yang $S-W$, Masuda $R$, Walker $R F$. Role of selected endogenous peptides in growth hormone-releasing hexapeptide activity: analysis of growth hormone-releasing hormone, thyroid hormone-releasing hormone, and gonadotropin-releasing hormone. Endocrinology, 130 : 2579-2586. 1992.

2) Bowers CY, Momany FA, Reynolds GA, Hong A. On the in vitro and in vivo activity of a new synthetic hexapeptide that acts on the pituitary to specifically release growth hormone. Endocrinology, $114: 1537-1545.1984$.

3) Bowers CY, Reynolds GA, Durham D, Barrera CM, Pezzoli SS, Thorner MO. Growth hormone (GH)-releasing peptide stimulates $\mathrm{GH}$ release in normal men and acts synergistically with GH-releasing hormone. J. Clin. Endocrinol. Metab., 70: 975-982. 1990.

4) Bowers CY, Sartor AO, Reynolds GA, Badger TM. On the actions of the growth hormonereleasing hexapeptide, GHRP. Endocrinology, $128: 2027-2035.1991$.

5) Bowers CY. GH releasing peptides - structure and kinetics. J. Pediatr. Endocrinol., $6: 21-31$. 1993.

6) Casanueva FF. Physiology of growth hormone 


\section{GH Release by KP 102 in Cattle}

secretion and action. Acromegaly, $21: 483-517$. 1992.

7) Cheng $\mathrm{K}$, Chan WW-S, Barreto A Jr, Convey EM, Smith RG. The synergistic effects of His-D -Trp-Ala-Trp-D-Phe-Lys- $\mathrm{NH}_{2}$ on growth hormone $(\mathrm{GH})$-releasing factor-stimulated $\mathrm{GH}$ release and intracellular adenosine 3', 5'monophosphate accumulation in rat primary pituitary cell culture. Endocrinology, 124: 2791-2798. 1989.

8) Croom Jr WJ. Leonard ES, Baker PK, Kraft LA, Ricks CA. The effects of synthetic growth hormone releasing hexapeptide BI 679 on serum growth hormone levels and production in lactating dairy cattle. J. Dairy Sci. [Suppl. 1], 67: 109 (Abstract). 1984.

9) Enright WJ, Chapin LT, Moseley WM, Zinn SA, Tucker HA. Growth hormone-releasing factor stimulates milk production and sustains growth hormone release in Holstein cows. J. Dairy Sci., 69 : 344-351. 1986.

10) Enright WJ, Chapin LT, Moseley WM, Tucker HA. Effects of infusions of various doses of bovine growth hormone releasing factor on growth hormone and lactation in Holstein cows. J. Dairy Sci., 71 : 99-108. 1988.

11) Frohman LA, Downs TR, Chomczynski P. Regulation of growth hormone secretion. Frontiers in Neuroendocrinology, $13: 344-405.1992$.

12) Gluckman PD, Breier BH, Davis SR. Physiology of the somatotropic axis with particular reference to the ruminant. J. Dairy Sci., 70 : 442-466. 1987.

13) Hashizume $T$, Soliman EB, Kanematsu $S$. Effects of pituitary adenylate cyclase-activating polypeptide (PACAP), prostaglandin $E_{2}$ $\left(\mathrm{PGE}_{2}\right)$ and growth hormone releasing factor (GRF) on the release of growth hormone from cultured bovine anterior pituitary cells in vitro. Domest. Anim. Endocrinol., 11 : 331-337. 1994.

14) Hashizume T, Sasaki K, Sakai M, Tauchi S, Masuda $\mathrm{H}$. The effect of new growth hormone -releasing peptide (KP 102) on the release of growth hormone (GH) in goats. Anim. Sci. Technol. (Jpn.), 68: 247-256. 1997.

15) Jansson J-O, Downs TR, Beamer WG, Frohman LA. The dwarf "little" (LIT/LIT) mouse is resistant to growth hormone releasing peptide (GHRP-6) as well as to GH-releasing hormone (GRH). Endocrinology, 118 (Suppl.) : 397.1986.

16) Johke T. Effects of TRH on circulating growth hormone, prolactin and triodothyronine levels in the bovine. Endocrinol. Jpn., 25:1926. 1978.

17) Korbonits M, Grossman AB. Grow th hormonereleasing peptide and its analogues. Novel stimuli to growth hormone release. TEM., 6 : 43-49. 1993.

18) Laron Z. Growth hormone secretagogues. Clinical experience and therapeutic potential. Drugs, 50:595-601. 1995.

19) Momany FA, Bowers CY, Reynold GA, Hong $A$, Newlander K. Conformational energy studies and in vitro and in vivo activity data on growth hormone-releasing peptides. Endocrinology, $114: 1531-1536.1984$.

20) Pihoker C, Middleton R, Reynolds GA, Bowers CY, Badger TM. Diagnostic studies with intravenous and intranasal growth hormonereleasing peptide- 2 in children of short stature. J. Clin. Endocrinol. Metab., 80 : 2987-2992. 1995.

21) Roh $S-G$. Matsunaga N, Hidaka S, Hidari $H$. Characteristics of growth hormone secretion responsiveness to growth hormone-releasing peptide-2 (GHRP-2 or KP 102) in calves. Endocrine J., 43: 291-298. 1996.

22) Sawada H. Effect of newly developed analogue of growth hormone releasing peptide [D-AlaD- $\left.\beta \mathrm{Nal}-\mathrm{Ala}-\mathrm{Trp}-\mathrm{D}-\mathrm{Phe}-\mathrm{Lys}-\mathrm{NH}_{2}(\mathrm{KP}-102)\right]$ on growth hormone secretion in adult male rats. J. Nippon Med. Sch., 62 : 142-149. 1995 (in Japanese).

23) Soliman EB, Hashizume T, Kanematsu $S$. Effect of growth hormone ( $\mathrm{GH}$-releasing peptide (GHRP) on the release of GH from cultured anterior pituitary cells in cattle. Endocrine J., $41: 585-591.1994$.

24) Soliman EB, Hashizume T, Kanematsu S. The combined effect of PACAP, GHRH, and SRIF on bovine $\mathrm{GH}$ release in vitro. Anim. Sci. Technol. (Jpn.), 66: 130-133. 1995.

25) Soliman EB, Hashizume $T$, Kanematsu $S$. Effect of angiotensin II on the release of grow th hormone from cultured anterior pituitary cells in cattle. Anim. Sci. Technol. (Jpn.), $66: 823-829.1995$.

26) Vale W, Grant G, Amoss M. Blackwell R. Guillemin R. Culture of enzymatically dispersed anterior pituitary cells: Functional validation of a method. Endocrinology, 91 : 562-572. 1972 .

27) Wakabayashi K. Life Science Personal Computer Series 5, Arrangement of Experimental Data (PC-8801, 9801).44-57, 90-133. Baihukan. 
Tokyo, 1984.

28) Wu D, Chen $\mathrm{C}$, Katoh K, Zhang J, Clarke IJ. The effect of GH-releasing peptide-2 (GHRP-2 or KP 102) on GH secretion from primary cultured ovine pituitary cells can be abolished by a specific GH-releasing factor (GRF) receptor antagonist. J. Endocrinology, 140 : R9-R13.
1994.

29) Wu D, Chen C, Zhang J, Katoh K, Clarke I. Effects in vitro of new growth hormone releasing peptide (GHRP-1) on grow th hormone secretion from ovine pituitary cells in primary culture. J. Neuroendocrinology, 6:185-190. 1994.

\title{
新しい成長ホルモン放出ペプチド（KP 102）のin vitro および in vivoにおけるウシ成長ホルモン放出効果
}

\author{
橋爪 力・柳本正澄・貝沼 周・長野りさ・森脇敬子 \\ 大槻健治・佐々木浩一・桝田博司・平田統一
}

岩手大学農学部, 盛岡市 020

第二世代日の新しい成長ホルモン $(\mathrm{GH})$ 放出ペプチド，KP 102 (D-Ala-D-B Nal-Ala-Trp-D-PheLys- $\mathrm{NH}_{2}$, 別名 GHRP-2）のウシ $\mathrm{GH}$ 放出効果を in vitro 扰よび in vivo で検討した. KP 102 と GH 放

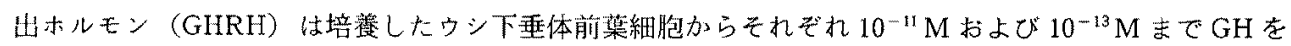
放出させた $(\mathrm{P}<0.05)$. KP $102\left(10^{-8} \mathrm{M}\right)$ と GHRH $\left(10^{-8} \mathrm{M}\right.$ あるいは $\left.10^{-10} \mathrm{M}\right)$ を同時添加すると, 両 ペプチトによる $\mathrm{GH}$ 放出の付加効果が見られた $(\mathrm{P}<0.05)$. ソマトスタチン $\left(\mathrm{SS}, 10^{-3} \mathrm{M}\right)$ は KP 102 $\left(10^{-8} \mathrm{M}\right)$ と GHRH $\left(10^{-8} \mathrm{M}\right)$ による GH 放出を抑制させた（P<0.05)。また KP 102 と GHRHによる $\mathrm{GH}$ 放出の付加効果は SS 存在下でも認められた $(\mathrm{P}<0.05) .20 \mu \mathrm{g} / \mathrm{kg} \mathrm{BW}$ の KP 102 の静脈内投与は子 ウシの末梢血中 $\mathrm{GH}$ 濃度を有意に増加させた $(\mathrm{P}<0.05)$. KP $102(20 \mu \mathrm{g} / \mathrm{kg} \mathrm{BW})$ と GHRH $(0.25 \mu \mathrm{g} /$ $\mathrm{kg} \mathrm{BW}$ )を同時投与すると， 10 分および 20 分後の血中 $\mathrm{GH}$ 濃度はをれぞれの単独投与時の值に比へ， 有意に高い値を示した $(\mathrm{P}<0.05)$. KP 102 と $\mathrm{GHRH}$ 同時投与時の投与 60 分間にお污る $\mathrm{GH}$ 放出反応曲 線トの面積（AUC）はKP 102 単独投与時に比べ有意に高い值を示したが（P<0.05）, GHRH 単独投与 時と比べると有意差は諗められなかった，本研究の結果は KP 102 はウシの $\mathrm{GH}$ 放出を刺激すること， また KP 102 は GHRH やSS と相互的に作用して GH を放出させることを示唆している.

日畜会報, 68 (5)：450-458, 1997 